Bulgarian Academy of Sciences. Space Research and Technology Institute.

Aerospace Research in Bulgaria. 31, 2019, Sofia

DOI: https://doi.org/10.3897/arb.v31.e12

\title{
COMPARISON OF OBLIQUE SHOCK WAVE ANGLE IN ANALYTICAL AND NUMERICAL SOLUTION
}

\author{
Assen Marinov \\ Aviation Faculty, National Military University \\ e-mail: asen_aerodynamics@abv.bg
}

Keywords: Subsonic aircraft, Shock wave angle, Wave drag.

\begin{abstract}
The drag of the subsonic aircraft is largely formed by the skin friction drag and lift-induced drag [2]. At transonic flight occurs shock wave. Determination of shock wave angle is important part of design of every aircraft, which working in supersonic airflow regimes. Formation of shock waves cause formation the wave drag. The wave drag could account about $35 \%$ from total drag of aircraft. Shock wave angle is directly linked with the intensity of itself.

This work compares shock wave angle calculations using analytical and numerical solving methods.
\end{abstract}

\section{Introduction}

For analytical solve of shock wave angle are used conservation equations of mass, momentum, and energy [1].

Consider that flow is steady, inviscid and adiabatic flow with no body forces, continuity equation is:

$$
\oiint_{S} \rho V \cdot d S=0 .
$$

The continuity equation for an oblique shock wave is:

$$
\rho_{1} V_{1 n}=\rho_{2} V_{2 n}
$$

\section{Momentum equation}

The integral form of the momentum equation can be resolved into two components - tangential and normal to the shock wave.

Tangential component: 
(3)

$$
\oiint_{S}(\rho V \cdot d S) V=-\oiint_{S} p d S
$$

(4) $\quad V_{1 t}=V_{2 t}, \quad\left(S_{1}=S_{2}\right)$.

The normal component:

(5) $\quad p_{1}+\rho_{1} V_{1 n}^{2}=p_{2}+\rho_{2} V_{2 n}^{2}$.

\section{Energy equation}

If consider, that flow is steady, inviscid, adiabatic and without body forces, then energy equation reduce to:

$$
\oiint_{S} \rho\left(e+\frac{V^{2}}{2}\right) V \cdot d S=-\oiint_{S} p V \cdot d S .
$$

For ideal gas:

(7) $\quad h_{1}+\frac{V_{1 n}^{2}}{2}=h_{2}+\frac{V_{2 n}^{2}}{2}$.

Deduce: changes across an oblique shock wave are governed only by the component of velocity normal to the wave.

\section{Analytical solving method}

Since equation (4), tangential components of the velocity, remain the same, while normal component decreases across the shock, the flow is deflected by angle $\theta$ toward the shock front after passing it [1].

Considering that: $M_{1 n}=M_{1} \sin \beta$ and $M_{2 n}=M_{2} \sin (\beta-\theta)$,

$$
\frac{\tan \beta}{\tan (\beta-\theta)}=\frac{(\gamma+1) M_{1}^{2} \sin ^{2} \alpha}{(\gamma-1) M_{1}^{2} \sin ^{2} \alpha+2}
$$

One of possible solution of this equation is:

(9) $\tan \theta=2 \cot \beta\left(\frac{M_{1}^{2} \sin ^{2} \beta-1}{M_{1}^{2}(\gamma+\cos 2 \beta)+2}\right)$.

Equation (8) determines angle $\theta$, when set $M_{1}$ and $\beta$.

The other solution determines $\beta$, when set $M_{1}$ and $\theta$ [3]. 
(10) $\beta=\arctan \left[\frac{b+9 a \cdot \tan \mu}{2(1-3 a b)}\right.$

$$
\left.-\frac{c\left(27 a^{2} \tan \mu+9 a b-2\right)}{6 a(1-3 a b)} \cdot \tan \left(\frac{n}{3} \pi+\frac{1}{3} \arctan \frac{1}{c}\right)\right],
$$

$a=\left(\frac{\gamma-1}{2}+\frac{\gamma-1}{2} \tan ^{2} \mu\right) \tan \theta$;

$b=\left(\frac{\gamma+1}{2}+\frac{\gamma+3}{2} \tan ^{2} \mu\right) \tan \theta$;

$c=\sqrt{\frac{4(1-3 a b)^{3}}{\left(27 a^{2} c+9 a b-2\right)^{2}}-1}$,

where $\mathrm{n}=1$ for weak shock solution,

function $\beta=f(M, \theta, \gamma, n) \rightarrow$ function $\beta=f(1.5,12,1.4$, and 1$)$.

\section{Numerical solving method}

Another form of the solution shock wave angle $\beta$ is numerical solution, applying the fundamental laws of mechanics to a fluid gives the governing equations for a fluid.

A 2D geometry for the model have a deflection angle $\theta=12^{\circ}$. Cell zone condition for the surface body is defined as ideal gas. Fig. 1 shows boundary zones in the calculation domain.

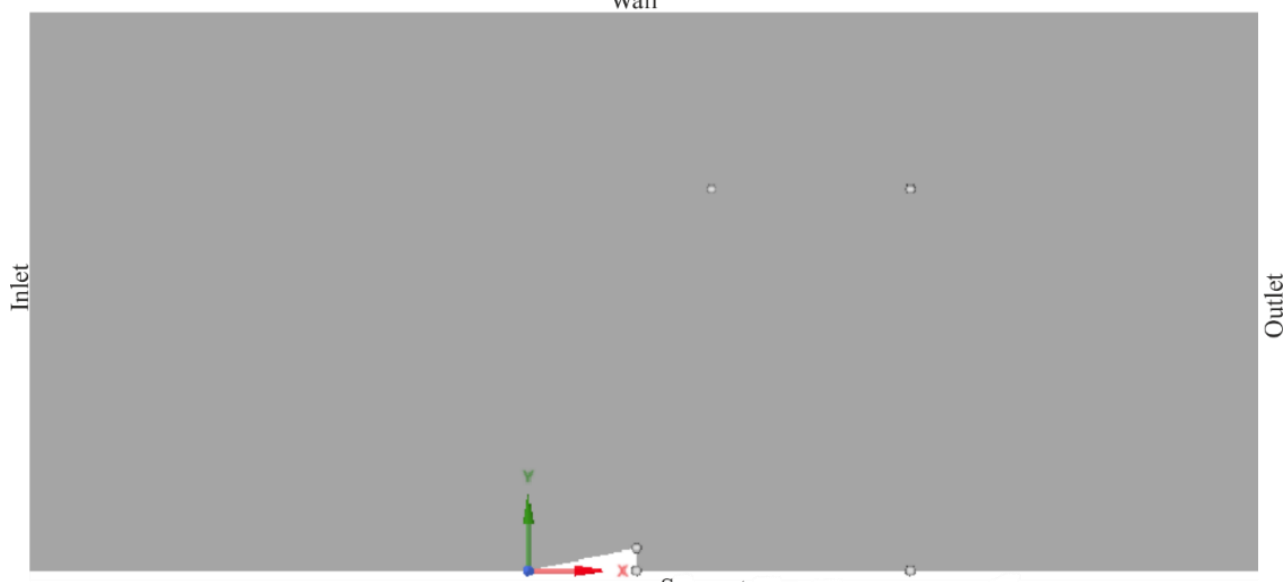

Symmetry

Fig. 1. Calculation domain 


\section{Results}

The results from analytical and numerical solutions for weak shock wave angle are presented in Table 1.

Table 1

\begin{tabular}{|c|c|c|}
\hline Method & Wave angle & Note \\
\hline Analytical & $64.35^{\circ}$ & Weak solution \\
\hline Numerical & $64.3^{\circ}$ & Weak solution \\
\hline
\end{tabular}

The color of Fig. 2 indicates the changing Mach area of the shock wave.

For a set Mach number of each value of the flow deviation angle after the shock wave $\theta$, correspond two values of angle $\beta$. The smaller angle value corresponds to a weak shock wave (supersonic airflow after the shock wave), while at the higher angle value of the the shock wave corresponds to a strong shock wave (subsonic velocity of the airflow after the shock wave). When body is with a wedge shape, always realizes a weak shock wave (Fig. 3).

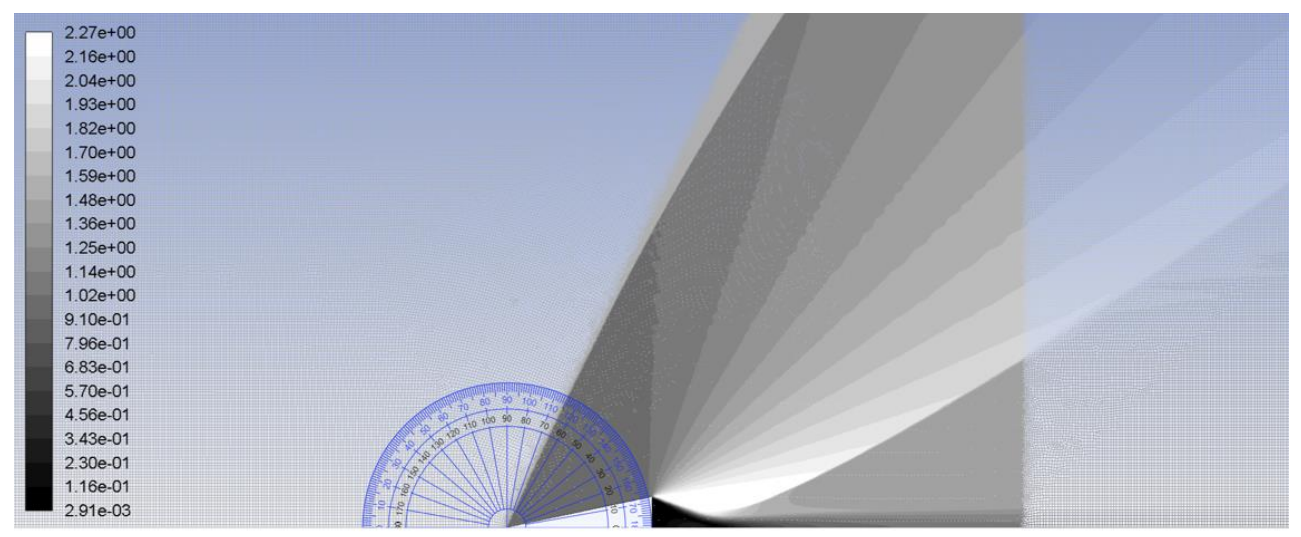

Fig. 2. Mach area of the shock wave 


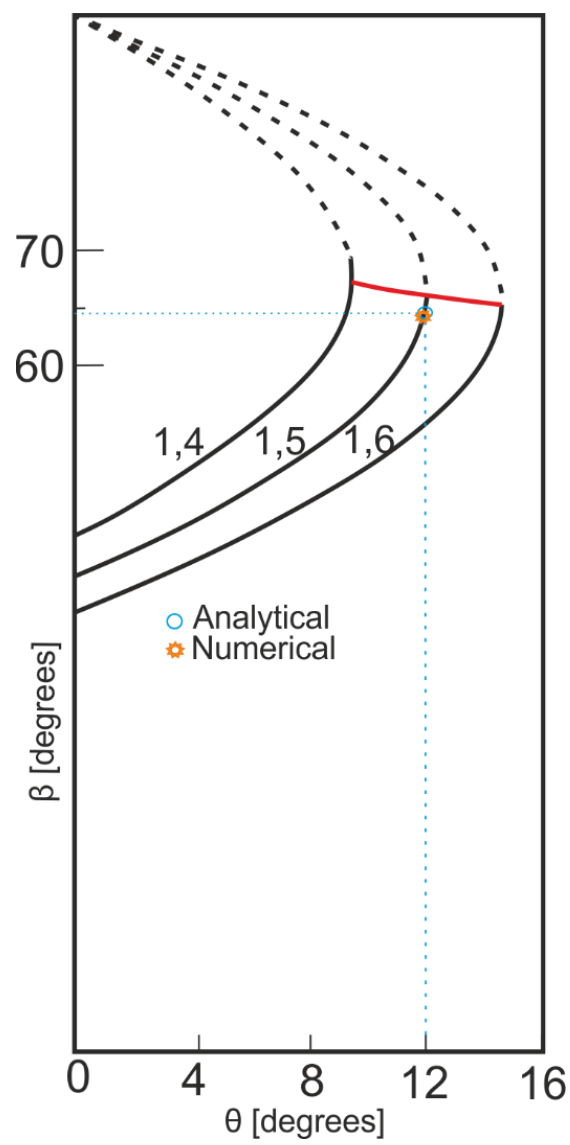

Fig. 3. $\beta=f(\theta)$

\section{Conclusions}

The simulation of shock wave angle has been carried out using analytical and numerical methods and carried out and the following conclusions can be drawn:

- The CFD simulation is able to predict precisely shock wave angle;

- A reasonably good agreement was obtained between analytical and numerical methods, when determining shock wave angle.

\section{References}

1. Anderson, J., Fundamentals of Aerodynamics, McGraw-Hill series in aeronautical and aerospace engineering, 2017, ISBN 978-1-259-12991-9. 
2. Kambushev, M., S. Biliderov, Determination of aerodynamic coefficients necessary for the control of MAVs, International scientific journal TRANS MOTAUTO WORLD, 2017, pp. 94-97. ISSN 2367-8399

3. Lael vonEggers Rudd, Mark J. Lewist, Comparison of shock calculation methods, Journal of Aircraft, 1998, 35, 4, pp. 647-49. ISSN 0021-8669

\section{СРАВНЯВАНЕ НА НАКЛОНА НА УДАРНА ВЪЛНА ПРИ АНАЛИТИЧНО И ЧИСЛЕНО ПРЕСМЯТАНЕ}

\section{A. Маринов}

\section{Резюме}

В полет самолетите предизвикват във въздушния поток силни смущения. Тласкайки намиращия се пред тях въздух, те повишават налягането на въздушния поток толкова повече, колкото по-голяма е скоростта на полета. Ђгълът между допирателната към фронта на ударната вълна и вектора на скоростта се изменя по фронта. Като с отдалечаване от обтичаното тяло се намалява този ъгъл, което води и до намаляване на интензивността на скока на упльтнение.

Фронтът на скока на уплътнение разделя въздушния поток на смутена и несмутена част, като в смутената част настьпва съществено изменение на параметрите на въздушния поток.

Колкото е по-голям ьгълът на наклон на скока на уплътнение, толкова по-съществено нарастват плътността и налягането зад него. Това води до съществено изменение на силите, които действат на обтичаното тяло, което от своя страна налага да се търсят способи за точно определяне на съответния ьгъл на наклон. 